\title{
The renin-angiotensin system in refractory heart failure: clinical, hemodynamic and hormonal effects of captopril and enalapril
}

\author{
G. A. Turini, B. Waeber AND H. R. Brunner \\ Department of Medicine, Centre Hospitalier Universitaire Vaudois, Lausanne. Switzerland
}

KEY WORDS: Congestive heart failure, saralasin, captopril, enalapril (MK 421), renin, angiotensin, norepinephrine, hemodynamics.

Studies using a competitive inhibitor of angiotensin II (saralasin) or converting enzyme inhibitors (teprotide, captopril, enalapril) have established that the renin-angiotensin system participates in the control of vascular tone in congestive heart failure both in experimental settings and in patients. In man. the marked decrease in left ventricular filling pressure and the variable increase in stroke volume induced by renin-angiotensin blockade suggests that angiotensin II actively constricts venous as well as arteriolar vascular beds. Captopril, in doses of 25 to $150 \mathrm{mg}$ p.o. TID, maintains its efficacy during chronic administration with persistent clinical and hemodynamic improvement as well as increased exercise tolerance. In our experience, enalapril, $10 \mathrm{mg}$ p.o., improves cardiac function within 4 to $6 \mathrm{~h}$ as reflected by a $30 \%$ decrease in left ventricular filling pressure, a $28 \%$ increase in stroke volume in the face of unchanged heart rate. Clinical improvement, enhanced exercise tolerance and characteristic hormonal responses suggest that enalapril also maintains its efficacy during long-term treatment. Chronic angiotensin II converting enzyme inhibition appears to be a major advance in the treatment of patients with severe congestive heart failure, refractory to digitalis and diuretics.

In patients with congestive heart failure, the occurrence of a compensatory increase in venous and arteriolar tone often causes further deterioration in pump performance. The factors responsible for this vasoconstriction include enhanced sympathetic nerve activity and possibly hyperreactivity of the vascular wall to pressor stimuli. The renin-angiotensin system also has been shown to participate in the complex regulation of vascular tone of such patients.

Patients with congestive heart failure frequently fail to excrete sodium and lack the ability to maintain normal sodium balance. Because angiotensin II is a major stimulus of aldosterone secretion, it could theoretically be expected that blockade of the reninangiotensin system might also reverse to some extent sodium retention. The purpose of this report is to review the role of renin in congestive heart failure and the clinical efficacy of various drugs inhibiting the renin angiotensin system, including enalapril, a new orally active converting enzyme inhibitor.

Requests for reprints to G. A. Turını. M D. Dept. of Medicine. C H.U.V.. 1011 Lausanne. Swltzerland.
The renin-angiotensin system in congestive heart failure

The secretion of renin is stimulated by sodium depletion, decreased renal perfusion and increased sympathetic nerve activity ${ }^{(1)}$. In the plasma, renin acts on renin substrate to produce angiotensin I which is converted, mostly at the level of the pulmonary circulation, to its active form angiotensin II by a converting enzyme. Angiotensin II, a powerful vasoconstrictor, stimulates aldosterone secretion by the adrenal cortex and acts directly in the brain to elicit thirst ${ }^{(2)}$. Thus stimulation of the renin-angiotensin-aldosterone hormonal system may increase systemic vascular resistance and total body fluid and sodium.

It has been shown in animals with experimental congestive heart fallure due to pressure or volume overload, that the renin-angiotensin system is actively implicated in the maintenance of blood pressure ${ }^{(3-7)}$. In these animals, plasma renin activity and aldosterone rose markedly immediately following development of heart failure and ensung hypo- 
tension. As a consequence, plasma volume increased, blood pressure was restored to normal and both plasma renin activity and aldosterone returned to baseline values. Some animals, however, did not reach their control arterial pressure and showed a persistent increase in plasma renin activity and aldosterone ${ }^{(3)}$.

Studies of patients with chronic heart failure refractory to digitalis and diuretics have revealed plasma renin activity varying from low to very high levels ${ }^{(8-10)}$. Frequently, patients with heart disease due to different etiologies and with a wide range of clinical severity were pooled for analysis. It is not ruled out, however, that the activity of the renin-angiotensin system in congestive heart failure may well vary according to the cause of heart fallure. On the other hand, plasma renin activity appears more consistently elevated during episodes of acute cardiac decompensation than in the chronic stage of heart failure ${ }^{(11)}$.

In the past, the best way to evaluate the function of a hormone was to unmask its action by removing the organ producing it. Accordingly, the role of the renin system has been investigated by binephrectomy, obviously a very crude and non-specific approach. In the early seventies, the development of agents antagonizing the effect of renin has opened a new, more physiological way to study the role of the renin-angiotensin system. Such inhibitors act either at the receptor level as competitive antagonists or angiotensin II (saralasin) ${ }^{(12)}$, or in blocking the enzyme which converts the inactive angiotensin I into the active octapeptide angiotensin II (teprotide. captopril, enalapril) ${ }^{(13-15)}$.

\section{Competitive angiotensin II blockade}

In our laboratory, saralasin (Eaton laboratories) was administered to 15 patients with congestive heart failure due to various etrologies ${ }^{(10)}$. Figure 1 shows the relationship between left ventricular filling pressure and stroke index in 13 of them, before and during saralasin infusion $\left(1-10 \mathrm{ng} \mathrm{kg}^{-1} \mathrm{~min}^{-1}\right)$. Eight patients decreased their blood pressure, whereas five did not change or even increased it. Left ventricular filling pressure fell in all but one, often with no change and sometimes with an increase in stroke index. The marked fall in left ventricular filling pressure cannot be explained solely by a decrease in arteriolar tone and impedance but strongly suggest, in addition, a decrease in venous tone.

The initial plasma renin activity of the patients

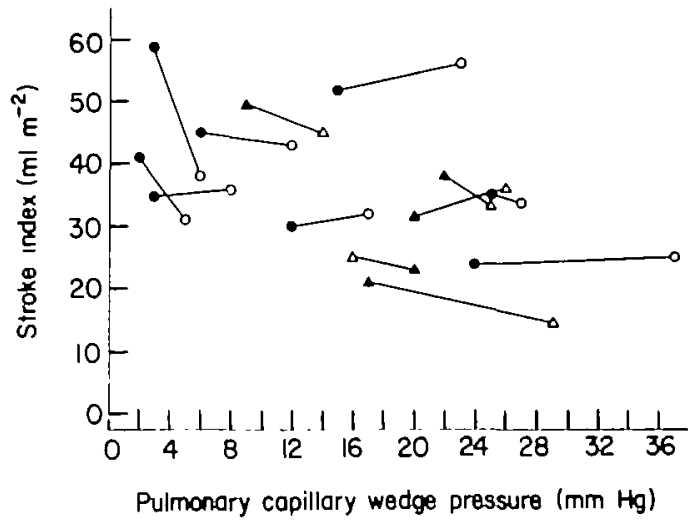

Figure $l$ Left ventricular function curves of 13 patients who had an infusion of saralasin. $O, \Delta=$ before and $O$, $\boldsymbol{\Delta}=$ after saralasin All but one pattent who had increased arterial pressure experienced improvement in left ventricular function. From Turini el al. ${ }^{(10)}$.

according to their arterial pressure response to saralasin is illustrated in Fig. 2. Those patients whose arterial pressure did not decrease had a mean plasma renin activity of $2 \cdot 0 \pm 0.58 \mathrm{ng} \mathrm{ml}^{-1}$, a value not significantly different from that of five controls. In contrast, patients responding with a fall in arterial pressure had a mean plasma renin activity of $8 \cdot 1 \pm 1 \cdot 6$ $\mathrm{ng} / \mathrm{ml}$ (mean \pm s.e.m.). Some patients with

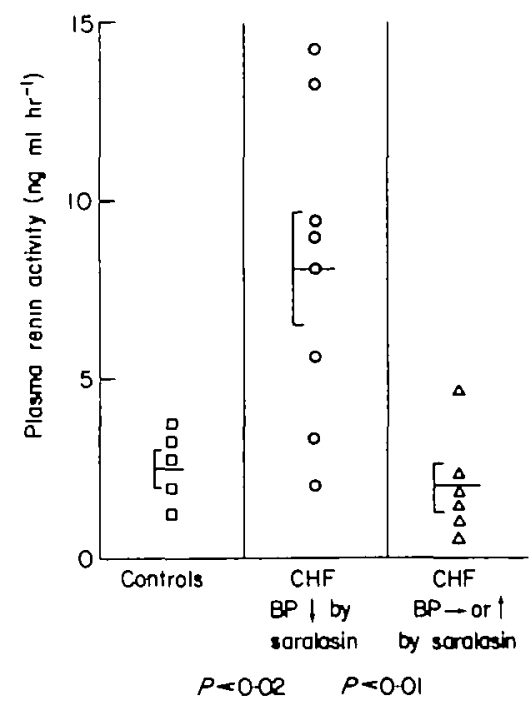

Figure 2 Initial plasma renin activity of controls $(\square)$, and patients with congestive heart failure who had a decrease $(O)$ or no change or an increase $(\triangle)$ in arterial pressure in response to saralasin infusion. The patients who had a decrease in blood pressure had significantly higher renin levels $(P<001)$. From Turıni et al. ${ }^{10 !}$. 
apparently 'normal' plasma renin activity also responded with a fall in arterial pressure.

This study of saralasin has established for the first time that the renin-angiotensin system plays an important role in controlling pre- and afterload of patients with congestive heart failure ${ }^{(16)}$. Furthermore, it has demonstrated that angiotensin II blockade improves pump function of the heart in most cases. This may have come as a certain surprise since angiotensin II had been reported to exert a positive inotropic effect ${ }^{(17,18)}$. The study of saralasin is of particular interest, since this compound, which is a competitive antagonist of angiotensin $I I$ at the receptor level, is the most specific inhibitor of the renin system. Saralasin has, however, the shortcoming of many competitive antagonists, that is to have agonistic or angiotensin II-like properties, which can lead to an increase in vascular tone under certain circumstances, e.g. when plasma renin activity is very $l o w^{(10)}$. Moreover, since it is an octapeptide with a relatively short half-life, it has to be infused intravenously which makes it unsuitable for longterm therapy.

\section{Angiotensin converting enzyme inhibition}

The first converting enzyme inhibitor available for clinical investigation, teprotide, is a nonapeptide and must therefore also be administered parenterally which renders chronic blockade impractical in patients. Its acute effect has been evaluated in patients with congestive heart failure ${ }^{(19.20)}$. The results of these studies were similar to those obtained with saralasin, though suggesting a more pronounced arteriolar dilatation following converting enzyme inhibition.

\section{CAPTOPRIL}

In 1976, captopril (E.R. Squibb), the first orally active converting enzyme inhibitor, became available ${ }^{(14)}$. When it was administered to normal volunteers, $20 \mathrm{mg}$ p.o. was sufficient to block within $15 \mathrm{~min}$ for over $2 \mathrm{~h}$ the pressor response to exogenous angiotensin $\mathrm{I}^{(21)}$.

Captopril was then given to patients with severe refractory heart failure ${ }^{(22-28)}$. The doses used varied between 6.25 and $150 \mathrm{mg}$ p.o. Within 1 to $3 \mathrm{~h}$, a significant fall in mean arterial pressure, in left ventricular filling pressure and in right atrial pressure was observed. The decrease in left ventricular filling pressure ranged from 20 to $45 \%$. Simultaneously, stroke index rose by 15 to $30 \%$ while heart rate was not accelerated. All indices returned to baseline within 3 to $8 \mathrm{~h}$ after drug administration depending on the dose.

The marked decrease in left ventricular filling pressure with a variable increase in stroke index observed in most patients suggests that captopril acts both on the arterial and the venous side of the circulation. The decrease in systemic vascular resistance and mean arterial pressure was not unexpected, since captopril has been used extensively to reduce the blood pressure of hypertensive patients. The fall in preload may have been less expected since there still exists some controversy on whether angiotensin II induces venous constriction ${ }^{(2)}$. The effect of converting enzyme inhibition on the venous side could also be indirectly mediated. Indeed, angiotensin II can stimulate sympathetic nerve activity via a central mechanism and in addition facilitate norepinephrine release by terminal nerve endings. It is therefore noteworthy that converting enzyme inhibition has been shown to decrease plasma norepinephrine levels in some patients with congestive heart failure ${ }^{(19.22)}$ whereas, in contrast, the plasma concentration of this hormone has been reported to increase after discontinuation of captopril therapy ${ }^{(29)}$. It is also possible that captopril interferes with the pressor action of catecholamines.

Thus, we have observed in the rat a decrease in the pressor response to norepinephrine following captopril administration ${ }^{(30)}$. Since angiotensin converting enzyme is also partly responsible for the inactivation of bradykinin ${ }^{(31)}$ the decrease in preload could theoretically be attributed to accumulation of vasodilating hormone. However, in experimental studies, we have not found any evidence for a bradykinin mediated effect of captopril(32). Moreover, saralasin is also known to decrease preload although it is not believed to influence bradykinin metabolism ${ }^{(10)}$. Thus, bradykının probably does not play an important role in the captopril mediated effect on preload and it seems more likely that this is related to decreased angiotensin II levels.

In many patients with congestive heart failure. measured plasma renin activity was not a reliable predictor of the hemodynamic response to renin angiotensin inhibition. To date, it is still not clear which factors govern renin secretion nor what determines vascular sensitivity to angiotensin II in patients with congestive heart failure. As a consequence it is not possible to determine what renin level is appropriate for a given hemodynamic state. Accordingly, it is also not surprising that in some 
patients with seemingly 'normal' plasma renin activity, blockade of the renin-angiotensin system induced a marked improvement in cardiac function. Thus, in patients with congestive heart failure, the measurement of plasma renin activity has serious limitations when used as an index of the physiological role of the system.

Though many patients with congestive heart failure have been treated with captopril for a prolonged period of time, relatively few long-term hemodynamic results have been published so far. Table 1 summarizes hemodynamic studies in a total of 52 patients carried out after two to six months of captopril 25 to $150 \mathrm{mg}$ p.o. t.i.d. ${ }^{125.26 .33 .341}$. The table demonstrates that the hemodynamic improvement persists in this group of severely ill patients and that there exists no real tachyphylaxis. It is of note that the magnitude of the acute hemodynamic effect has not been a good predictor of the long-term response to captopril. Sustained hemodynamic improvement has also been documented by radionuclide studies ${ }^{(35)}$.

During chronic captopril administration. numerous investigators have observed a persistent and marked increase in exercise tolerance as assessed by ergometry ${ }^{(25-27.36)}$. These changes seem to have been statistically significant, also when compared to placebo controls (E.R. Squibb, pers. comm.). Subjective improvement has been very striking, often within $1 \mathrm{~h}$ of drug administration, even in patients with only modest improvement of hemodynamics. Such an effect was never observed during saralasin administration and one might wonder if it could be due to activation of enkephalins by the converting enzyme inhibition ${ }^{(37)}$. Captopril being a drug with a relatively short duration of action, it could be feared that its sudden discontinuation induces a rebound phenomenon. Fortunately such a withdrawal syndrome does not seem to occur ${ }^{(29)}$

Among 498 patients with congestive heart failure treated for up to two years (E.R. Squibb, pers. comm.), arterial hypotension has been observed in $24 \%$ and skin rash and/or pruritus in $7 \%$. One to $3 \%$ have experienced taste alteration, gastrointestinal discomfort or renal impairment which may lead to hyperkalemia. In our experience hyperkalemia and hypotension is best avoided by decreasing or stopping diuretic therapy before starting captopril therapy. Similarly symptomatic hypotensive episodes during captopril treatment can be managed by temporarily reducing or interrupting administration of diuretics. Other side-effects usually subside when the dose is decreased.

\section{ENALAPRIL}

Many new converting enzyme inhibitors are currently under investigation ${ }^{(38.39)}$. Among those, enalapril (MK 421, Merck Sharp and Dohme) appears to be particularly potent. In normal volunteers, $10 \mathrm{mg}$ p.o. were sufficient to block the response to exogenous angiotensin I within 2 to $4 \mathrm{~h}$ and the effect lasted for more than $10 \mathrm{~h}^{(40)}$.

We recently investigated five men and one woman aged 55 to 72 with class III (four patients) or IV (two patients) chronic congestive heart failure despite salt restriction, digitalis and diuretic treatment. Before the study, all patients were on a constant salt intake of 2 to $3 \mathrm{~g} /$ day. Digoxin was maintained whereas the diuretic was interrupted on the morning of the procedure. After an overnight fast, the patients underwent cardiac catheterization in the supine position. A Swan-Ganz and a short polyethylene arterial catheter were introduced percutaneously. Pressures were measured with Statham P23Dd transducers and recorded on a Hewlett Packard 14560 recorder. Cardiac output was measured by thermodilution with a Roche Bioelectronic model 535095 monitor, using injectıons of $5 \mathrm{ml}$ of iced isotonic solution. After a rest period of $45 \mathrm{~min}$, baseline hemodynamic measurements were obtained. Then, $10 \mathrm{mg}$ of enalapril was given by mouth and hemodynamic measurements were repeated every hour for a minimum of $4 \mathrm{~h}$. Blood samples were drawn before and $4 \mathrm{~h}$ after enalapril administration. The following parameters were measured in the plasma: renin activity ${ }^{(41.42)}$, angiotensin converting enzyme activity ${ }^{(41.43)}$, angiotensin $\mathrm{II}^{(40.44)}$, aldosterone $^{(41.45)}$, plasma norepinephrine and epinephrine levels ${ }^{(46)}$. Before cardiac catheterization, four patients underwent an exercise tolerance test on a treadmill using the Naughton protocol ${ }^{(47)}$ with the modification that each step lasted only 2 min. After two months of therapy, exercise tolerance test and plasma measurements were repeated in these patients.

Figure 3 summarizes the hemodynamic response to enalapril. Within 4 to $6 \mathrm{~h}$, at the time of maximum effect, mean arterial pressure had decreased from an initial $85 \pm 4.2$ to $72 \pm 3.2 \mathrm{~mm} \mathrm{Hg}$ (mean \pm s.e.m.) with a concomitant fall in pulmonary capillary wedge pressure from $20 \pm 2.8$ to $14 \pm 2.8 \mathrm{~mm} \mathrm{Hg}(P<0.001)$ while cardiac index had increased from $1.5 \pm 0.06$ to $1.8 \pm 0.11 \mathrm{~min}^{-1} \mathrm{~m}^{-2}(P \cdot 0.05)$ due to a rise in stroke index from $18 \pm 1.7$ to $23 \pm 2.5 \mathrm{ml} \mathrm{m}^{-2}$ $(P<0.05)$. Heart rate did not change. Right atrial pressure decreased from $8 \pm 2.4$ to $6 \pm 1.9 \mathrm{~mm} \mathrm{Hg}$ 


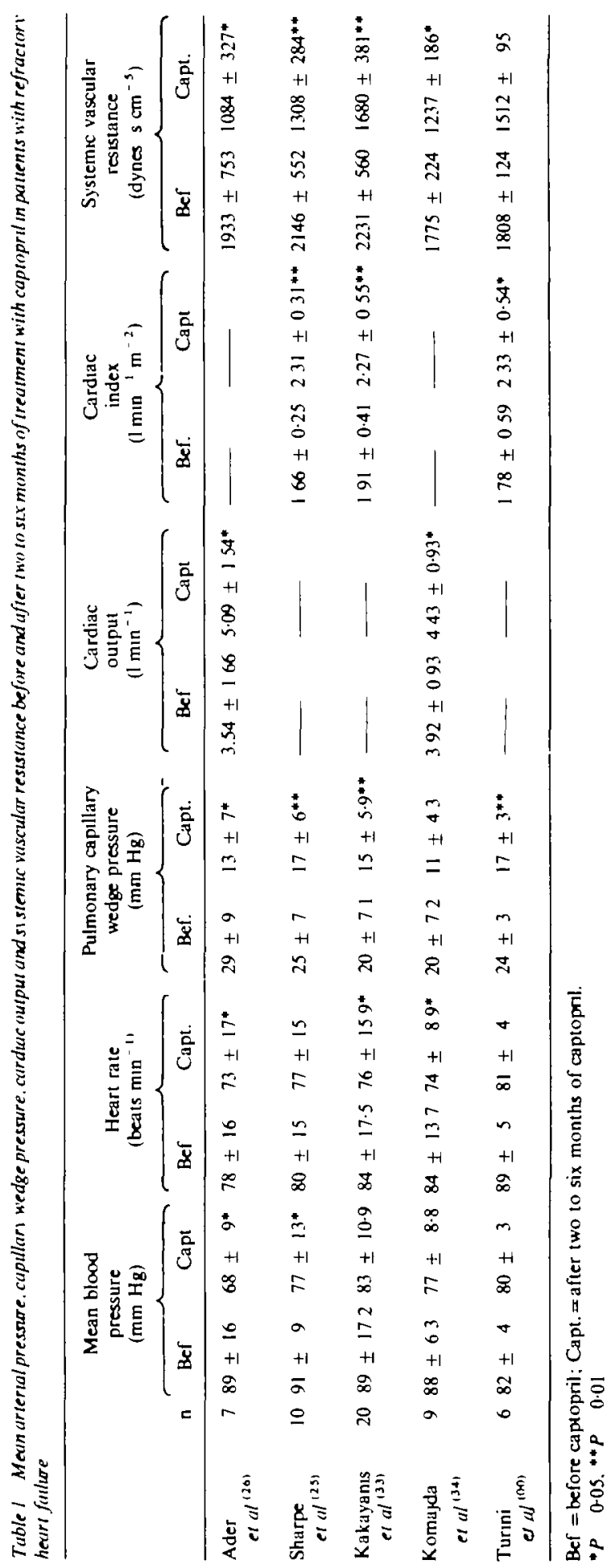


(o)

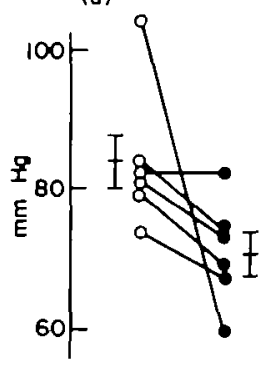

(c) (b)

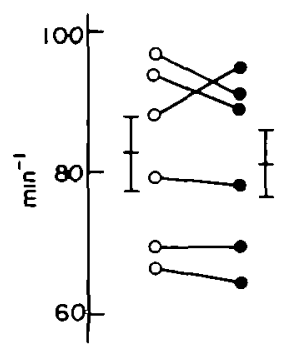

(d)
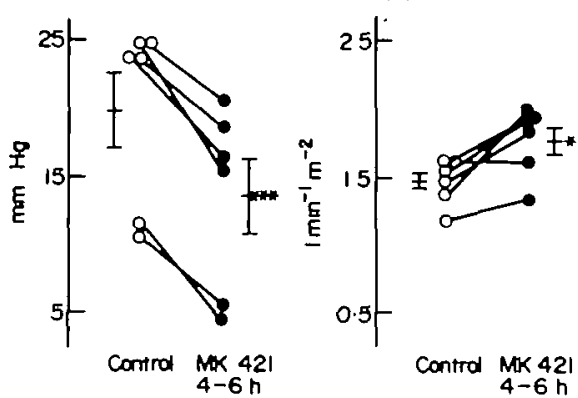

Figure 3 (a) Mean blood pressure, (b) pulse rate. (c) pulmonary capillary wedge pressure and (d) cardiac index of six patients with refractory congestive heart failure before (O) and $4-6 \mathrm{~h}$ following administration of enalapril (MK 42I) $10 \mathrm{mg}$ p.o. (๑). ${ }^{*} P<0.05,{ }^{* * *} P<0.001$. Results are mean \pm s.e.m.

$(P<0.005)$. The decrease in arterial pressure was well tolerated by all patients.

The relationship between stroke index and pulmonary capillary wedge pressure before enalapril administration and at the time of peak effect (4 to $6 \mathrm{~h}$ ), is shown in Fig. 4. A fall in left ventricular filling pressure coincided with an increase in stroke index in five patients and with no change in one. These results suggest that enalapril like captopril reduces both arteriolar and venous tone.

The time sequence of the changes in mean arterial, right atrial and pulmonary capillary wedge pressure as well as in cardiac index following oral administration of $10 \mathrm{mg}$ enalapril is illustrated in Fig. 5 . Compared to the effect of captopril, onset of action was slower and peak effect was not reached before $4 \mathrm{~h}$, when many patients treated with captopril have already returned to baseline conditions.

Figure 6 depicts hormonal measurements before and $4 \mathrm{~h}$ after the initial enalapril administration in four patients studied on a long-term bases. Plasma renin activity rose from $8 \cdot 4 \pm 3 \cdot 1$ to $31 \pm$ $13 \cdot 1 \mathrm{ng} \mathrm{ml}^{-1} \mathrm{~h}^{-1}$. Plasma angiotensin converting

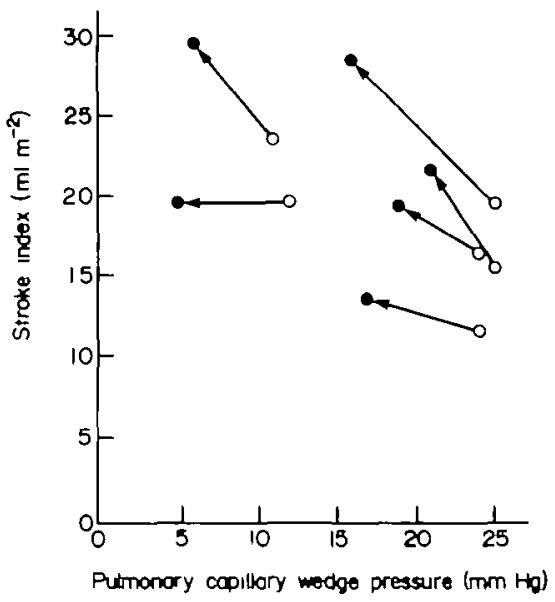

Figure 4 Relationship between pulmonary capillary wedge pressure and stroke volume index before $(O)$ and 4-6 h following administration of enalapril (MK 421) $10 \mathrm{mg}$ p.o. (O).
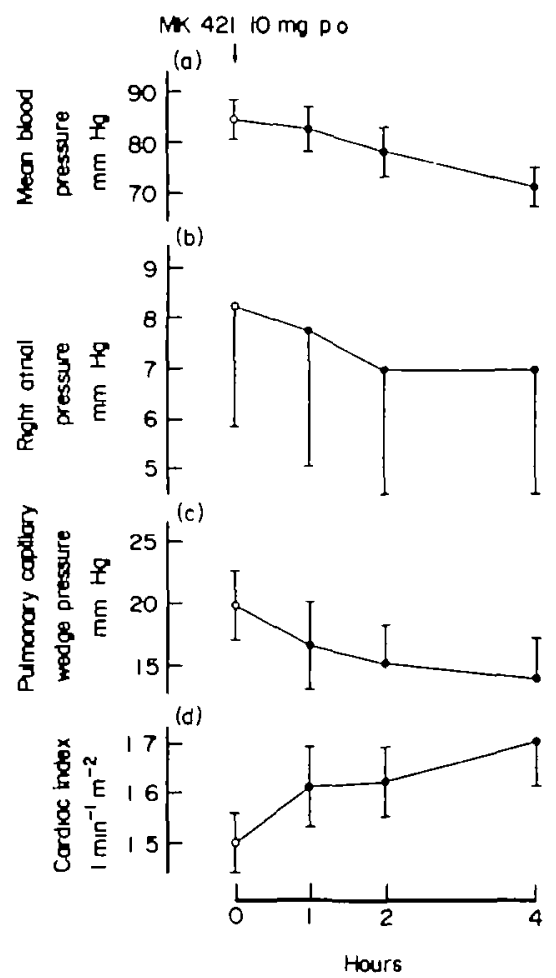

Figure 5 Time sequence during the inttial $4 \mathrm{~h}$ of changes in (a) mean blood pressure. (b) right atrial pressure, (c) pulmonary capillary wedge pressure and (d) cardiac index following administration of enalapril (MK 421) $10 \mathrm{mg} \mathrm{po}$. $\mathrm{n}=6$. Results are mean \pm s.e $\mathrm{m}$. 
(0)
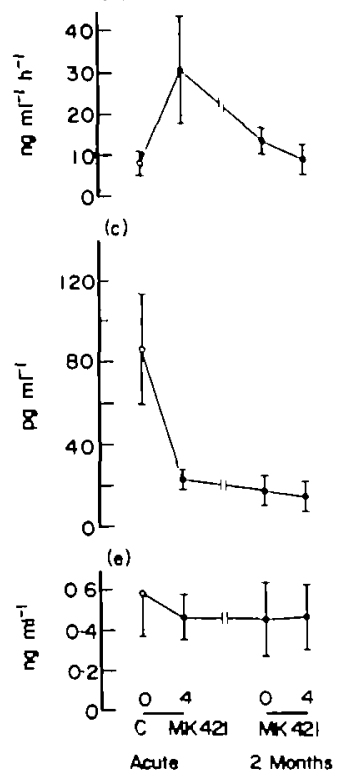
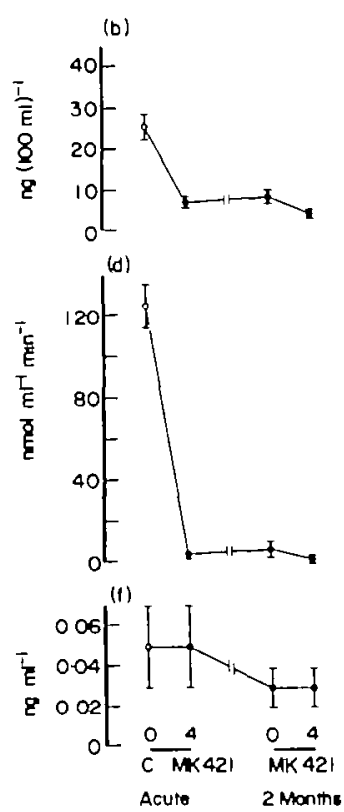

Figure 6 Plasma levels of (a) renin activity, (b) aldosterone, (c) angiotensin II, (d) converting enzyme activity, (e) norephinephrine and ( $f$ epinephrine before and $4 \mathrm{~h}$ after the acute administration of enalapril (MK 421) $10 \mathrm{mg}$ p.o. The same parameters were remeasured after two months of enalapril therapy, $10 \mathrm{mg}$ p.o. b.i.d., before and $4 \mathrm{~h}$ after the morning dose of enalapril. $n=4$. Results are mean \pm s.e.m

enzyme activity fell from $125 \pm 11$ to $5 \pm 2 \mathrm{nmol} \mathrm{ml}^{-1}$ $\min ^{-1}$, plasma aldosterone from $26 \pm 3.3$ to $7.5 \pm$ $1.3 \mathrm{ng} \mathrm{dl}^{-1}$ and plasma norepinephrine from $0.59 \pm$ 0.21 to $0.47 \pm 0.11 \mathrm{ng} \mathrm{ml}^{-1}$. Plasma epinephrine was very low at $0.05 \pm 0.02 \mathrm{ng} \mathrm{ml}^{-1}$ and did not change.

All six patients were placed on chronic treatment consisting of $10 \mathrm{mg}$ q.d. or b.i.d. They all reported a marked decrease in symptoms and a net subjective improvement in functional capacity. In 4 of these chronically treated patients, plasma renin activity had returned to the pre-treatment mean of $8.8 \pm 4.0$ $\mathrm{ng} \mathrm{ml^{-1 }} \mathrm{h}^{-1}$ whereas plasma aldosterone, angiotensin II, angiotensin converting enzyme activity and norepinephrine remained markedly decreased (Fig. 6).

Each of the four patients, in whom a treadmill test was performed before enalapril treatment, increased his exercise capacity during long-term converting enzyme inhibition. This improvement was similar to that seen in patients after two months of treatment with captopril (Fig. 7). Indeed, all patients increased their treadmill performance by at least two stages.

Thus, in patients with chronic refractory congestive

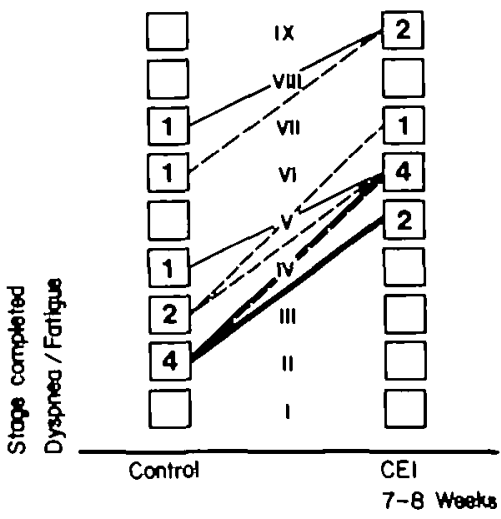

Figure 7 Exercise capacity according to a modified Naughton protocol before and after two months of treatment by captopril (-) or enalapril (----)

heart failure enalapril acutely enhances hemodynamic function by decreasing both preload and afterload. The clinical improvement, the increased exercise tolerance and the sustained hormonal effects observed after several weeks of therapy suggest that the effect of enalapril, like that of captopril, persists with long-term administration.

\section{Conclusions}

During the past decade, specific antagonists of the renin-angiotensin system have been developed. Saralasin is a competitive inhibitor of angiotensin II at the receptor level and teprotide, captopril and enalapril block the angiotensin converting enzyme and thereby the generation of angiotensin 11. All these compounds have been administered to patients with chronic refractory congestive heart failure and have produced a marked improvement of cardiac pump function. On the one hand, this strongly suggests that the renin-angiotensin system contributes to the excessive arteriolar and venous constriction characteristic of refractory congestive heart failure. On the other hand, chronic converting enzyme inhibition by captopril appears to provide a major advance in the treatment of these patients. Unlike vasodilators, it does not induce sodium retention, and neither tachyphylaxis nor rebound after discontinuation have been observed. Enalapril is a more recently developed converting enzyme inhibitor with a slower onset and a longer duration of action. Its hemodynamic effects are very similar to those of captopril and its beneficial effects in patients with congestive heart failure persist with prolonged therapy. 


\section{References}

(1) Davis JO. Freeman RH Mechanisms regulating renin release. Physiol Rev 1976; 56:1-56.

(2) Page IH, Bumpus FM, eds. Angiotensin Berlin. Heidelberg. New York: Springer-Verlag. 1974

(3) Watkins L Jr, Burton JA, Haber E, Cant JR. Smith $F W$, Barger $A C$. The renin-angiotensin-aldosterone system in congestive failure in conscious dogs. J Clin Invest 1976: 57: 1606-7.

(4) Davis JO. Pechet MM, Ball WC Jr. Goodking MJ. Increased aldosterone secretion in dogs with rightsided congestive heart failure and in dogs with thoracic inferior vena cava constriction. J Clin Invest 1957:36: 689.94.

(5) Davis JO. Adrenocortical and renal hormonal function in experimental cardiac failure. Circulation 1962:25. 100214 .

(6) Williams GM. Davis JO, Freeman RH, Deforrest JM. Seymour AA. Rowe BP. Effects of the oral converting enzyme inhibitor SQ 14225 in experimental high output failure. Am J Physiol 1979; 5: F541-5.

(7) McNamara RF. Schmid PG. Schmidt JA. Lund DD. Bhatnagar RK. Humoral regulation of vascular resistance after 30 days of pulmonary artery constricIton. Am J Physiol 1979; 236: H866-72.

(8) Brown JJ. Davis DL, Johnson VW. Lever AF. Robertson JIS. Renin relationships in congestuve cardiac failure, treated and untreated. Am Heart J $1970 ; 80: 32942$.

(9) Genest J, Granger P. De Champlain J. Boucher R. Endocrine factors in congestive heart failure. Am J Cardiol 1968; 22: 35-42.

(10) Turini GA. Brunner HR, Ferguson RK. Rivier JL. Gavras $H$. Congestive heart failure in normotensive man. Haemodynamics, renin. and angiotensin II blockade. Br Heart J 1978; 40: 1134-42.

(11) Dzau VJ, Colueci WS. Hollenberg NK. Williams GH. Relation of the renin-angiotensin-aldosterone system to clinical state in congestive heart failure. Circulation $1981 ; 63.645-51$.

(12) Pals DT, Masucci FD, Sıpos F. Denning GS Jr. A specific competitive antagonist of the vascular action of angiotensin I1. Circ Res 1971; 29: 664-72.

(13) Ondetti MA, Williams NJ, Sabo EF. Pluscec J. Weaver ER, Kocy $O$. Angiotensin-converting enzyme inhibitors from the venom of Bothrops jararaca. Isolation, elucidation of structure and synthesis. Biochemistry 1971; 10: 4033 .

(14) Ondetti MA, Rubin B, Cushman DW. Design of specific inhibitors of angiotensin-converting enzyme: new class of orally active antihypertensive agents. Science $1977 ; 196: 441-4$

(15) Patchett AA. Harris. Tristam EW. et al. A new class of angiotensin converting enzyme inhibitors. Nature 1980, 288: 280.3

(16) Turini GA, Brunner HR, Ferguson RK, Rivier JL. Gavras $H$. Improvement of cardiac function by angiotensin II blockade. Clin Res 1977: 25: 258 A (Abstract).

(17) Koch-Weser J. Nature of the inotropic action of angiotensin on ventricular myocardium. Circ Res $1965 ; 16.230-7$.
(18) Freer RJ. Pappano AJ. Peach MJ. et al. Mechanism for the positive inotropic effect of angiotensin II on isolated cardiac muscle. Circ Res 1976: 39: 178-82.

(19) Curtis C. Cohn JN. Vrobel T, Franciosa JA. Role of the renin-angiotensin system in the systemic vasoconstriction of chronic congestive heart failure. Circulation 1978; $58: 763-70$.

(20) Gavras H, Faxon DP. Berkoben J, Brunner HR, Ryan TJ Angiotensin converting enzyme inhibition in patients with congestive heart fallure. Circulation $1978 ; 58 \cdot 770-6$

(21) Ferguson RK. Turinı GA. Brunner HR. Gavras H. McKinstry DN. A specific orally active inhibitor of angiotensin-converting enzyme in man. Lancet 1977; $1: 775-8$

(22) Turini GA. Brunner HR. Gribic M. Waeber B. Gavras H. Improvement of chronic congestive heart failure by oral captopril Lancet $1979 ; 1: 1213-5$

(23) Davis R. Ribner HS, Keung E. Sonnenblick EH, LeJemtel TH. Treatment of chronic congestive hear failure with captopnl, an oral inhibitor of anglotensin converting enzyme. Engl J Med 1979; 301: 117-21.

(24) Mason DT, Hermanovich J. Evensen M. Awan NA. Oral captopnl in ambulatory management of severe congestive heart failure; sustained beneficial effects of ventricular function with 6 months therapy shown by cardiac catheterization, nuclear scintigraphy. echocardiography. treadmill exercise and symptomatology. Am J Cardiol 1980; 45: 411.

(25) Sharpe DN, Douglas JE, Coxon RJ. Long B. Lowdose captopril in chronic heart failure: acute haemodynamic effects and long-term treatment. Lancet $1980 ; 2: 1154-7$.

(26) Ader R, Chatterjee K, Ports T. Brundage B. Hiramatsu B. Parmley W. Immediate and sustained hemodynamic and clinical improvement in chronic heart fallure by an oral angiotensin-converting enzyme. inhibitor. Circulation 1980;61:931-7.

(27) Levine TB. Franciosa JA. Cohn JN. Acute and longterm response to an oral converting-enzyme inhibitor. captopril. in congestive heurt failure. Circulation 1980; 62: 35-41.

(28) Maslowskı AH. Ikram H. Nicholis MG. Espiner EA. Haemodynamic, hormonal and electrolyte responses to captopril in resistant heart failure. Lancet 1981,1 $71-4$.

(29) Maslowski AH, Nicholls MG, Ikram H, Espiner EA, Turner JG. Haemodynamic. hormonal, and electrolyte responses to withdrawal of long-term captopril treatment for heart failure. Lancet $1981 ; 2: 959-61$.

(30) Spertini F. Brunner HR, Waeber B. Gavras H. The opposing effects of chronic angiotensin-converting enzyme blockade by captopril on the responses 10 exogenous angiotensin $I 1$ and vasopressin vs. norepinephrine in rats. Circ Res 1981, 48: 612-8.

(31) Erdōs EG. Conversion of angıotensin I to angiotensin II Am J Med 1976;60*749-59.

(32) Textor SC, Brunner HR, Gavras H. Converting enzyme inhibition during chronic anglotensin II infusion in rats. Evidence against a nonangiotensin mechanism. Hypertension 1981, 3: 269-76.

(33) Kayanakis JG. Giraud P. Puel J. et al. Effets cliniques. hémodynamiques. biologiques de l'inhibition de 
l'enzyme de conversion dans l'msuffisance cardiaque chronique réfractaire. Nouv Presse Med 1981; 19: 1583-6.

(34) Komajda $M$, Eugène $M$, Evans J, Lecossier D. Grosgoeat $Y$. Traitement prolongé de linsuffisance cardiaque sévère par le captopril. Nouv Presse Med 1981; 19: 1587-91.

(35) Fouad FM. Tarazi RC. Bravo EL, Hart NJ. Castle LW, Salcedo EE. Long-term control of congestive heart failure with captopril. Am J Cardiol 1982, 49. 1489-96.

(36) Turini GA, Brunner HR. In: Journées de Réanimation de l'Hôpital Claude Bernard, Librairie Arnette, Paris. 1980: 307-15.

(37) Benuck M, Marks N. Co-ıdentity of brain angiotensin converting enzyme with a membrane bound dipeptidyl carboxypeptidase inactiving met-enkephalin. Biochem Biophys Res Commun 1979; 88: 215-21.

(38) Biollaz J. Burnier M. Turini GA, et al. Three new long-acting converting enzyme inhibitors; relationship between plasma converting enzyme activity and response to angıotensin 1. Clin Pharmacol Ther 1981; 29: $665-70$.

(39) Burnier M. Tunnı GA, Brunner HR. Porchet M. Kruithof D, Gavras H RHC 3659: a new orally acuve angiotensin converting enzyme inhibitor in normal volunteers. Br J Clin Pharmacol 1981; 12: 893-9.

(40) Brunner DB, Desponds G. Biollaz J, et al. Effect of a new angiotensin converting enzyme inhibitor MK42I and its lysine analogue on the components of the renin system in healthy subjects. Br J Clin Pharmacol 1981, 11: 461-7.

(41) Brunner HR, Gavras H. Waeber B, et al. Oral angiotensin-converting enzyme inhibitor in long-term treatment of hypertensive patients. Ann Intern Med $1979 ; 90 \cdot 19-23$.

(42) Sealey JE. Gerten-Banes J. Laragh JH. The renin system : variations in man measured by radioimmunoassay or bioassay. Kidney Int 1972; 1: 240 53.

(43) Cushman DW. Cheung HS. Spectrophotometric assay and properties of the anglotensin-converting enzyme of rabbit lung. Biochem Pharmacol 1971; 20: 163748.

(44) Düsterdieck G. McElvee G. Estımation of angiotensen II concentration in human plasma by radioimmunoassay. Some applications to physioJogical and clinical states. Eur J Clin Invest 1971: 2 : $32-8$.

(45) St Cyr MJ. Sancho JM. Melby JC. Quantitation of plasma aldosterone by radioimmunoassay. Clin Chem 1972; 18: 1395-402.

(46) Peuler JD. Johnson G. Simultaneous single isotope radioenzuymatic assay of plasma norepinephrine. epinephrine and dopamıne. Life Sci 1977; $21: 625$.

(47) Patterson JA, Naughton J. et al. Treadmill exercise in assessment of the functional capacity of patients with cardiac disease. Am J Cardiol 1972; 30: 757-62. 
. 